\title{
Formation Mechanism and Development Path of Productive Service Industry Cluster
}

\author{
Hao Zheng \\ School of Business Administration, Shandong University of Finance and \\ Economics, Jinan City, Shandong Province, 250014, China
}

\begin{abstract}
The industrial cluster is a kind of phenomenon that the related industrial activities concentrate on the geography or the specific location. The geographical concentration of an industry can form the relative competitive advantages compared with the same industry, and become an effective model for the development of industry in the world. With the development of economic globalization and information technology, modern productive service industry appears the trend of clustering, and the trend is very obvious in the important node cities in the world. Based on the author's learning and practical experience, this paper first analyzed the characteristics of the productive service industry, and then discussed the formation mechanism of producer service industry cluster, and finally put forward the development paths of productive service industry cluster.

Keywords: Productive Services Industry; Cluster; Formation Mechanism; Development Path
\end{abstract}

\section{Introduction}

Productive service industry, also known as "producer services", refers to a service industry that provides intermediate inputs for producers (industry, agriculture and other services), and it has the nature of enterprises. Since 1970s, the productive service industry has been developing rapidly in the world, and its sustained and 
rapid development has attracted the attention of many scholars at home and abroad[1]. In the context of global economic integration, the rise of industrial clusters is a form of industrial spatial organization that formed by the industry to create competitive advantages. While the produce of modern service industry is accompanied by the development of information technology and knowledge economy, thus it uses the modern new technology, new formats and new service modes to transform and upgrade traditional service industries, to create demands and guide consumption, and provides the society with high value-added, multilevel, knowledge-based production services and life services.

\section{Characteristics of productive service industry}

Productive service industry can be seen as a part of the supply capacity of the economy, it reflects the ability of the economy that adjusts to changes in the environment, and represents a payment mechanism for the organization to regulate economic change. Productive service industry is different from other traditional service industries. First, the intermediate input is the most essential feature of producer services, which is different from other types of traditional services. Coffey (1991), Noyelle \& Staback (1984) and other scholars have pointed out that the inputs of producer service is intermediate, and it plays the role of intermediate demands in finance or investment in production services so that it can improve the production efficiency of the producer[2].

Second, the strong relevance of industry is another characteristic of productive service industry. The relationship between productive service industry and manufacturing industry is very close. Some productive services industry are gradually separated from the manufacturing industry, but they are inextricably linked with the manufacturing industry, and they can drive the development of many departments. In addition, the productive service industry also has strong positive correlations between each other.

Third, productive service industry is the link between human capital and intellectual capital. Gruble \& Walker (1989) points out that the vast majority of human capital and intellectual capital go into the production process through those manufacturers, who are the main users of high-tech manpower and scientific and technological knowledge. Fourth, productive service industry has the trend of "externality", and the industrial distribution is concentrated. Producer services are more inclined to the urbanization of the economy, that is, the increase in the size of the city and the corresponding decrease in the cost of producer services[3]. According to the results of the study, Eberts \& Randal 
(1998) found that producer services are concentrated in metropolitan areas and then become the core of the region's industrial activities.

\section{Formation mechanism of productive service industry cluster}

\subsection{Producer services promote the development of industrial clusters by increasing the added value of manufacturing industry}

As a kind of flexible productive material, services get into the field of production gradually, which has an important influence on improving economic efficiency and competitiveness. Producer service has become an important factor in determining the added values of modern manufacturing industry, and the improvement of the overall level of manufacturing industry and product quality depends on the additional services and the integration of the service industry. The experience of developed countries shows that with the development of industrialization, the development of producer services is an important foundation to promote the development of industry's high degree of processing, technology and added-value.

Upgrading the technology contents and added values is the core issue of the development of industrial clusters. In particular, with the global division of manufacturing and the extension of industrial chain, more and more values created by enterprises come from producer service activities which ends in the $\mathrm{R}$ $\& \mathrm{D}$ and marketing value chains[4]. The operation of the industrial chain is more dependent on producer services, and the efficiency of service industry has more and more important influence on the whole industry chain and even on the regional economic development. The improve of the competitiveness of China's manufacturing industry increasingly relies on the developed financial insurance, computer network and information, e-commerce, modern logistics, management consulting, accounting, lawyers and other knowledge intensive services which center on other business services.

Of course, a single manufacturing enterprise is different from manufacturing industry cluster. The industrial cluster is composed of interrelated enterprises and related institutions, and the development of its competitiveness does not depend on the development of individual enterprises, but on the common development of stakeholders in group. 


\subsection{Producer services promote the development of industrial clusters by reducing transaction costs}

In some sense, the industrial cluster is based on the comparative advantages of the specialized division of labor and cooperation and the concentration in the geographical location, and there is a very high degree of specialization in the industrial cluster. However, in the process of improving production efficiency, the division of labor needs to coordinates different participants' interests: transaction cost problems[4]. The deeper and more extensive division of labor, the higher the transaction costs, and it is possible to offset the interests of the division of labor. China's labor costs and the costs of land use are low, and the costs of product manufacturing have competitive advantages all over the world. However, all types of transaction costs of enterprises are high, mainly reflected in the imperfect credit system, the not developed third party logistics, the backward financial and insurance industry, the low level legal service level and so on,so they have a great influence on the efficiency of enterprises. At present, the competitiveness of many industrial clusters can not be improved and it is difficult to achieve sustainable development, which has a great relationship with the lack of producer services.

\subsection{Producer services promote the development of industrial clusters by enhancing regional innovation capability}

Industrial cluster and regional innovation system can coexist in one region, and industrial cluster is the important support of regional innovation system. The industrial cluster has brought about a variety of innovative elements, which provides essential conditions for the formation of regional innovation system. In recent years, the product life cycle is becoming shorter and shorter, and the technology is developing rapidly, thus it is necessary for manufacturing enterprises to combine innovation with production. The vast majority of local industrial clusters in China are made up of small enterprises, which are specialized in different production links in the production chain system, and almost there is no independent enterprise has the internal control to promote the innovation and development of industrial clusters. Therefore, in the industrial cluster, innovation is not activities of a single innovation entity, but is a kind of group activity that all kinds of innovative subjects interact with each other and share in cooperation, so they need to have more knowledge to participate in the innovation and they need to cooperate in a innovative way. 


\subsection{Producer services promote the development of industrial clusters by integrating enterprises into the global value chain}

Productive service industry promotes the development of industrial clusters by further integrating enterprises into the global value chain. With the development of economic globalization, the international division of labor is becoming more and more obvious, and the formation of the global production network makes the value creation link of the products dispersed in different countries and regions. As a production organization form between the market and the enterprise, the industrial cluster is more and more embedded in global value chain (GVC) under the trend of economic globalization, and it has become an important part of the global value chain[5]. Therefore, the development of industrial clusters not only needs to explore the internal resources of the cluster and emphasize internal links, but also needs to obtain external resources and pays attention to external links, actively interacts with the economic actors in the global value chain, and constantly adjusts their own ways of embedding the global industrial value chain. The main advantage of the local industrial cluster is the low costs of labor intensive processing manufacturing, however, with the further penetration of globalization and the acceleration of the pace of international industrial transfer, these advantages will gradually lose and a lot of cheap goods are being limited by the world market capacity and the resistance of the importing countries.

\subsection{Producer services promote the development of industrial clusters by creating a good institutional environment}

The agglomeration of enterprises in a certain area does not necessarily lead to the improvement of the efficiency. Only when the establishment of the system of the region makes the transaction cost reduce to a certain extent, the economic benefits will be produced. Most of China's industrial clusters do not have perfect market regulation system and advanced enterprise system, and they rely on the interpersonal relationship network relationships and the high level of division of labor among small businesses between to overcome the disadvantages of market regulation, which conforms to China's social and cultural environment and plays a huge role in the initial stage of manufacturing industry cluster. However, in the process of economic growth, with the gradual improvement of China's market economy, this advantage has gradually become disadvantage. Modern enterprises tend to seek development space in the areas where having a relatively perfect system, high transparency, high efficiency of the government, and a legal market environment. 


\section{Industrial cluster development path based on productive service industry}

\subsection{According to the different development stages of different industrial clusters and different industrial clusters, focus on developing different producer services}

In different industrial clusters, producer services are in different stages, and in the different stages of the same industrial cluster, the demands for all types of producer services are also different. China's industrial clusters are mostly low cost manufacturing, their production modes are backward and their requirements for various services are different. Some production services are too high but not necessarily required by enterprises, and some producer services needed by enterprise have not been developed[6]. Therefore, it is necessary to carry out a detailed investigation on the status of industrial clusters and focus on developing different producer services according to the different development stages of industrial clusters and different industrial clusters.

\subsection{Increase the effective demands for producer services in manufacturing enterprises}

Manufacturing industry is the prerequisite and basis for the development of producer services, and the development of the productive service sectors must rely on the manufacturing industry, because the manufacturing industry is an important demand sector in productive service industry output. Without manufacturing, there is almost no social demand for these services. It is necessary to actively promote the manufacturing enterprises "external activities", and make the original services provided by the enterprises independent and market-oriented. Enterprises should focus on manufacturing and outsource the R \& D design, supply chain management, after-sale service and other links of the downstream of the product value chain, and rely on manufacturing agglomeration to expand the effective demands for producer services[7].

\subsection{Increase the Effective Supply of Producer Services, and Gradually Cultivate and Build Regional Service System}

Enterprises should increase the effective supply of producer services while expanding the demand for producer services, otherwise, their demands will not be met. At present, manufacturing enterprises in the industrial clusters are mainly in the stage of transformation and upgrading, capital, information, technology and talent have become key factors in the development of enterprises, but the 
effective supply corresponding to these elements of the production service is insufficient and the service level is low. To vigorously develop the productive service industry, we must construct the market environment that productive service industry needs to survive and develop, create the necessary institutional conditions for speeding up the development of service industry, expand market access, strengthen the service market competition, and introduce foreign capital services in areas where conditions are met.

\section{Conclusion}

Producer service cluster is mainly formed under the guidance of the government's industrial policy, while it is rarely formed by market forces, thus the effects of cluster network are not obvious. In view of the problems in the development of producer service industry, the government can consider changing the top-down model led by government into market driven bottom-up model. Government should mainly focus on the creation and fostering regional innovation environment, and should formulate special policies for enterprises clusters, give policy supports in technological innovation, land management, decision-making consultation, financing guarantee, personnel training, international market development etc.

\section{Acknowledgements}

The research work was supported by National Social Science Fund: Study on the Growth Strategy of Local Producer Service Enterprise Which is Embedded in the "Global Manufacturing and Service Chaos Modular Network" (NO. 13CGL042).

\section{References}

[1] Chen Xi, Lv Bin. Research on the Development Model of Small and Medium Sized City Service Industry Cluster. economic geography, 04, pp.105-111, 2014. [2] Qiu Ling. Spatial Agglomeration of Producer Services in Metropolis: a literature review. economist, 05, pp.97-104, 2014.

[3] Sun Huaping. Agglomeration and Evolution of Producer Services. Journal of Zhejiang Shuren University (SOCIAL SCIENCE EDITION), 03,pp.51-56, 2009.

[4] Liu Yi. Formation Mechanism of Service industry Cluster. Theory Journal of Guangdong University of Business, 05, pp.48-53, 2009. 
[5] Liu Yi, Xia long. The Formation Mechanism and the Mechanism of Service Industry Cluster:. international experience of Foreign Social Sciences, 06, pp.6468, 2009.

[6] Zheng Jichang, Xia Qing. Producer Service Industry Cluster. reform, 05, pp.145-148, 2010.

[7] Wang Xiaohong, Wang Chuanrong. The Transformation of Manufacturing Industry and Service Industry under the Condition of Industrial Transformation. reform, 09, pp.40-47, 2013. 